\title{
SUMMARY OF NORTHERN SAW-WHET OWL BANDING - 2008
}

HAROLD FISHER, R. R. 4, Site 1, Comp 231, Prince Albert, SK S6V5R2, E-mail: $<$ hfisher@skvelocity.ca>

This report summarizes the first full year of operation of a new Northern Saw-whet Owl (NSWO) banding station. Mist nets were set up periodically throughout 2008 as weather conditions and circumstances permitted with the objective of determining the presence of owls. During the spring banding season, two $12 \mathrm{~m}$ long nets (38-mm mesh) were used. During the autumn season, one 18-m net (32-mm mesh) was added, and on 15 September, a $12-\mathrm{m}$ net (60-mm mesh) was added. An audiolure recording of the male
NSWO call was broadcast at the netting site when nets were open. Netting began typically 1 hour after sunset and continued most evenings until midnight as circumstances permitted. During heavy flights, the nets were kept open later. The station was closed during rainy or windy weather.

In total, 289 NSWOs were captured in the mist nets in 2008, 29 during the spring season and 260 in the fall (Table 1). This total includes two recaptures of birds banded at other

Table 1: Net capture effort for Northern Saw-whet Owls at the Nisbet Forest Banding Station in 2008. One net hour is defined as one $12 \times 2-m$ mist net operated for $1 \mathrm{~h}$.

\begin{tabular}{|l|c|c|c|}
\hline Month & $\begin{array}{c}\text { Days } \\
\text { Open }\end{array}$ & $\begin{array}{c}\text { Net- } \\
\text { Hours }\end{array}$ & $\begin{array}{c}\text { NSWOs } \\
\text { Captured }\end{array}$ \\
\hline \hline January & 3 & 24 & 0 \\
\hline February & 0 & 0 & 0 \\
\hline March & 11 & 63 & 3 \\
\hline April & 14 & 111 & 26 \\
\hline May & 1 & 2 & 0 \\
\hline June & 0 & 0 & 0 \\
\hline July & 2 & 17.5 & 0 \\
\hline August & 11 & 96.25 & 3 \\
\hline September & 28 & 504.25 & 157 \\
\hline October & 21 & 454.5 & 100 \\
\hline November & 0 & 0 & 0 \\
\hline December & 0 & 0 & 0 \\
\hline \hline TOTAL & 91 & 1272.5 & 289 \\
\hline
\end{tabular}


Table 2: Northern Saw-whet Owl captures by age and sex (Project Ow/net) in 2008.

\begin{tabular}{|c|c|c|c|c|c|}
\hline Season & $\begin{array}{c}\text { Age } \mathbf{( \% )} \\
\text { <1 Year }\end{array}$ & $\begin{array}{c}\text { Age (\%) } \\
\text { >1 Year }\end{array}$ & $\begin{array}{c}\text { Male } \\
\mathbf{( \% )}\end{array}$ & $\begin{array}{c}\text { Female } \\
(\mathbf{\%})\end{array}$ & $\begin{array}{c}\text { Unknown } \\
(\mathbf{\%})\end{array}$ \\
\hline \hline March - April & 48.3 & 51.7 & 10.3 & 86.2 & 3.4 \\
\hline August - October & 56.5 & 43.5 & 12.3 & 67.3 & 20.4 \\
\hline
\end{tabular}

stations, and three same-station recaptures. It does not include sameseason recaptures of any kind. Age and sex-specific data are summarized in Table 2.

\section{Spring Banding}

Attempts at capturing NSWOs during spring migration have been relatively unproductive through much of western Canada, and few banding stations operate during this period. We set up mist nets periodically during the winter and into the spring as weather conditions permitted to determine the extent of NSWO overwintering. Our first NSWO was captured on $14 \mathrm{March}$, and the last on 19 April. Half of these birds were captured on 7 to 9 April, suggesting a relatively narrow window of spring flight. However, the results indicate that spring banding is feasible at this station.

\section{Autumn Banding}

The first bird captured after the breeding season was an after hatching year (AHY) female in full molt. This bird was captured on 13 August and was quite possibly a local bird. Two more NSWO were captured on 27 August, both hatching year (HY) birds and both bearing remnants of juvenile plumage. The first day on which we began to catch NSWOs in significant numbers was 7 September, and 23 October was the last date on which we caught owls in any number (3). The last owl was captured on 28 October.

Based on 2008 results, it appears the spring banding season at this

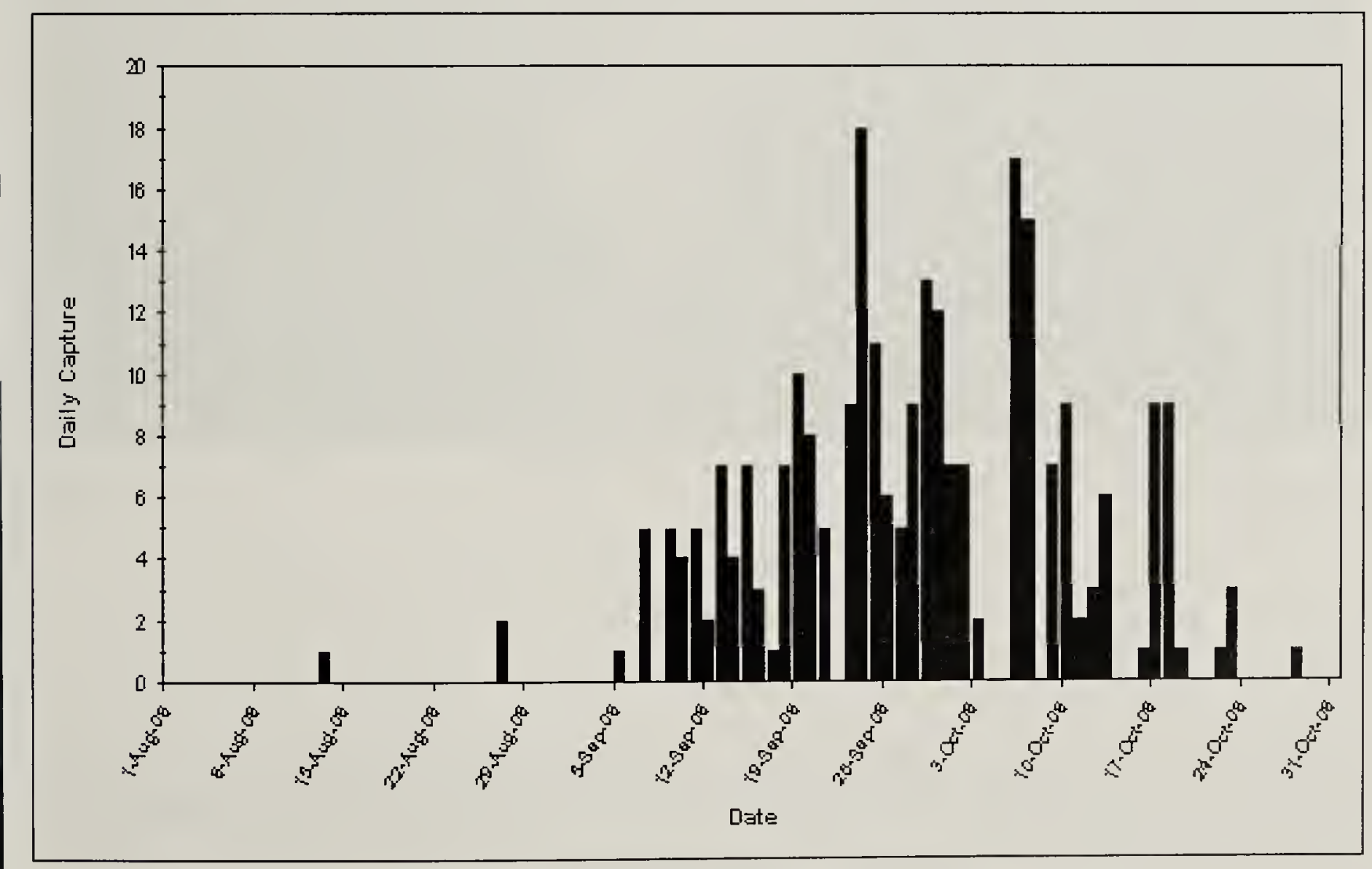

Figure 1: Northern Saw-whet Ow/s captured during autumn 2008

67 (1) March 2009 
station should run from 15 March through 20 April and the autumn season from 5 September to 25 October (Fig. 1). Of course, this does not preclude the possibility of catching NSWO during any season at this location as weather conditions and circumstances permit.

\section{Recaptures from the Nisbet Forest Station}

14 March 2008: recaptured \#092447323, an AHY male banded on 27 September 2007

12 September 2008: recaptured \#0924-53908, an SY female banded on 25 March 2008

30 September 2008: recaptured \#0924-47323 again

\section{Recaptures from other Stations}

27 September 2008: \#0894-62091, banded in Bigfork Minnesota on 19 October 2006

6 October 2008: \#0924-42865, banded in Edenwold, SK, on 28 September 2008

\section{Incidentals}

During the fall banding season we captured four Boreal Owls and three Long-eared Owls in the nets. After the NSWO season, we continued the mistnet operation with a BOOW audiolure and captured seven additional Boreal Owls by the end of November.

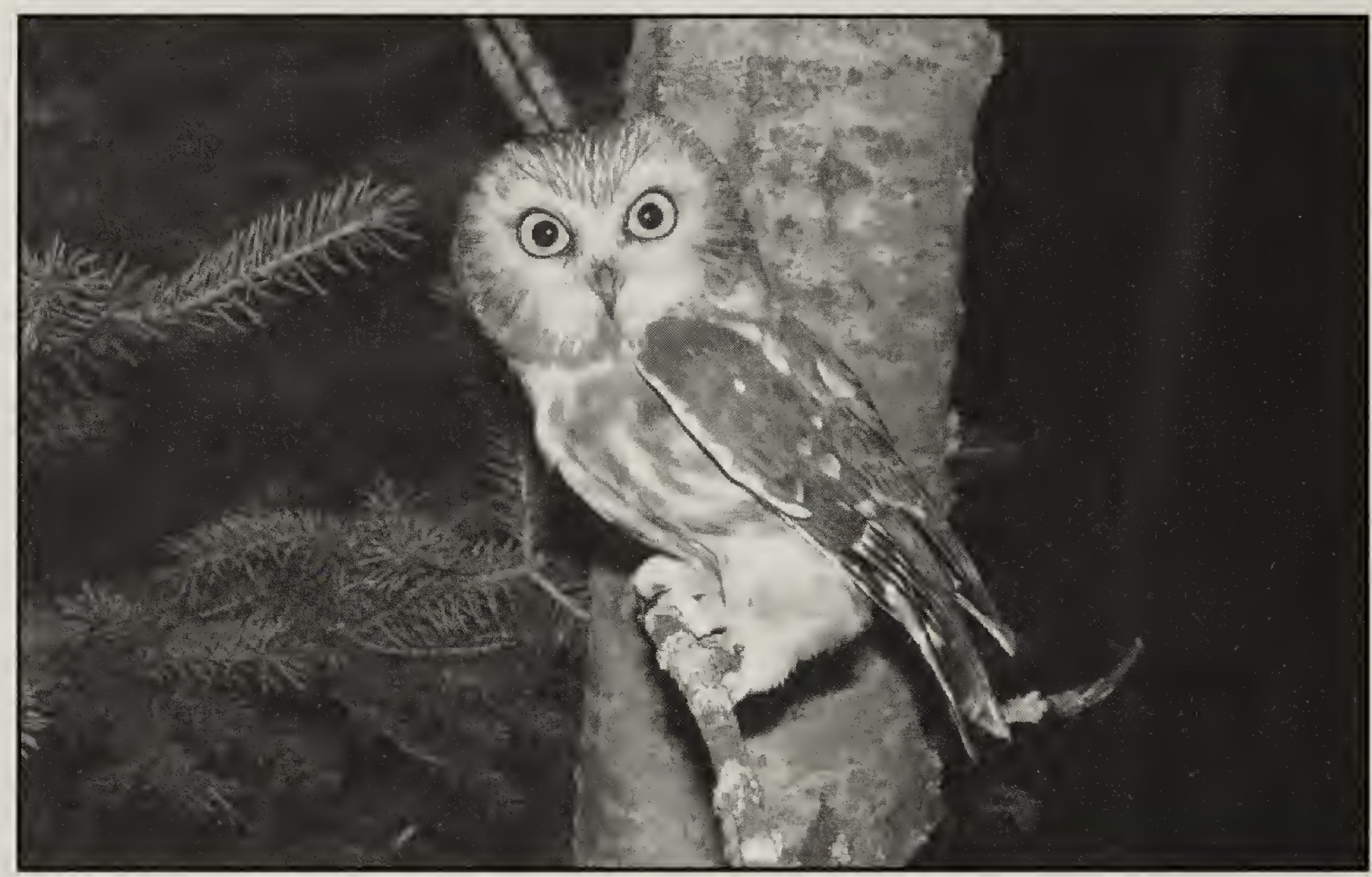

Northern Saw-whet Owl

H. Fisher

The sun, with all those planets revolving around it and dependent on it, can still ripen a bunch of grapes as if it had nothing else in the universe to do. - Galileo 